\title{
ARE YOU GETTING FULL BENEFITS FROM THE USE OF SOCIAL MEDIA? A REVIEW COMBINING THE CONCEPTS OF SOCIAL MEDIA, SOCIAL CAPITAL AND KNOWLEDGE SHARING
}

\author{
VOCÊ OBTEM TODOS OS BENEFÍCIOS DO USO DAS MÍDIAS \\ SOCIAIS ? UMA REVISÃO DE LITERATURA COMBINANDO \\ OS CONCEITOS DE MIIDIAS SOCIAIS, CAPITAL SOCIAL E \\ COMPARTILHAMENTO DO CONHECIMENTO
}

\author{
Rosangela Fritscher Santos ${ }^{1}$ \\ Mirian Oliveira ${ }^{1,2}$ \\ Marcirio Silveira Chaves ${ }^{1}$ \\ 1 Pontifical Catholic University of Rio Grande do Sul (PUCRS) - Porto Alegre, Brazil \\ 2 University of Lisbon (ISEG) - Lisbon - Portugal
}

\begin{abstract}
Purpose - The social media have become powerful tools that can be used to do much more than connecting relatives and friends, helping find a job or providing advertising space. This study aims to present the benefits of combining the subjects related to Knowledge Sharing, Social Media and Social Capital theory.

Design/methodology/approach - Literature review of 22 papers identified as relevant when combining the subjects Social Media, Social Capital and Knowledge Sharing. The 22 documents were subjected of content analysis.

Findings - The analysis of the literature revealed two fundamental roles for social media within organizations - an operational role - working as a channel or tool; a transformative role - used to support organizational strategy.

Research limitations/implications - The limitation of this study is related to the limited number of papers that resulted from the search.

Practical implications - The benefits of combining the three subjects include improvements on informal communication, better collaboration and cooperation, and a positive influence on job performance and innovation.

Originality/value - The proposed research agenda highlights the importance of future investigations into the sharing of tacit knowledge through Social Media; focusing on how to generate trust via Social Media and suggests research attention related to knowledge protection.
\end{abstract}

Keywords: knowledge sharing, social media, social capital, tacit knowledge, trust. 


\section{RESUMO}

Objetivo - As mídias sociais tem se tornado uma ferramenta relevante, que pode ser usada para mais atividades do que simplesmente conectar parentes e amigos como, por exemplo, auxiliando a encontrar trabalho ou como um espaço para propaganda. O objetivo desta pesquisa é apresentar os benefícios da combinação dos tópicos Compartilhamento do Conhecimento, Mídias Sociais e teoria do Capital Social.

Método - Revisão de literatura de vinte e dois artigos relevantes quando combinando os assuntos Mídias Sociais, Compartilhamento do Conhecimento e teoria do Capital Social. Os 22 artigos são submetidos a análise de conteúdo.

Resultados - A análise da literatura revelou dois papéis fundamentais para as mídias sociais dentro das organizações - um papel operacional - funcionando como um canal ou ferramenta; um papel transformador - usado para apoiar a estratégia organizacional.

Limitações da Pesquisa/Implicações - A limitação deste estudo está relacionada ao limitado número de artigos que resultaram da busca.

Implicações Práticas - Os benefícios de combinar os três assuntos incluem melhorias na comunicação informal, melhor colaboração e cooperação e uma influência positiva no desempenho do trabalho e na inovação.

Originalidade - Uma agenda de pesquisa é proposta para destacar a importância de investigações futuras sobre o compartilhamento de conhecimento tácito por meio das mídias sociais, focando em como gerar confiança pelas mídias sociais; sugere-se também atenção a pesquisas relacionadas à proteção do conhecimento.

Palavras-chave: compartilhamento de conhecimento, mídias sociais, capital social, conhecimento tácito, confiança.

\section{INTRODUCTION}

One way or another we are part of the global economy. Companies are running projects involving people spread around the world (Ellison, Gibbs \& Weber, 2015); distance learning is becoming increasingly common; newly graduated doctors in far-flung rural areas are supported by urban-based specialists (Somsakit et al., 2016). How do these people interact with each other? Many of them do so via the various forms of social media, which despite essentially being communication channels, the interactions within it carry knowledge. The flow of knowledge is critical for making organizations more efficient (Grant, 1996; Davenport and Prusak, 1998) and it needs a network and channels to be shared. Such a network can consist of people capable of meeting either face to face, or via technology that can help build social ties and connect people over great distances or sitting just a few steps away.

The Knowledge Management literature (KM) relates this discipline with Social Capital theory and with Social Media (Wasko and Faraj, 2005; Kankanhalli, Tan and Wei, 2005; Beck, Pahlke and Seebach, 2014) and other studies exploring KM's specific processes - knowledge sharing (Bharati, Zhang \& Chaudhury, 2015) with the latter two (Social Media and Social Capital theory). Social Media, due to its unique capabilities, such as interactivity, has been found to be useful in facilitating knowledge sharing (Kwahk and Park, 2016; Baehr and Alex-Brown, 2010) and in the creation of social networks, which are formed by social capital (Jarrahi, 2017). Both knowledge sharing using social media and the leveraging of social capital to share knowledge are subjects that have been studied for some time (Rode, 2016; Kim and Lee, 2006; Chiu, Hsu and Wang, 2006; Han and Hovav, 2013). The common point of using social tools and their social ties to share knowledge suggests these subjects work in a complementary 
way. Therefore, the purpose of this study is twofold: a) analyse the literature related to the Knowledge Sharing process, Social Media and Social Capital, and b) propose a research agenda highlighting the importance of future investigations into the sharing of tacit knowledge through Social Media. The paper discusses how Knowledge Sharing process, Social Media and Social Capital relate to each other, how Social Capital theory is used and the value of treating these three subjects together. The outcomes from the systematic literature review may benefit researchers by sharing the state of art on these subjects as well as pointing out opportunities of future research. For practitioners, having a consolidated view based on previous research may be useful when developing or adjusting personal or organizational strategies to get the full benefits from social media usage.

This paper is structured as follows: Section two presents a theoretical background about the three subjects; section three describes the criteria used to select the papers and how they were analysed; section four includes an analysis and discussion of the reviewed papers and the highlights the conclusions reached; and section five points out the research limitations and offers suggestions for future research.

\section{THEORETICAL BACKGROUND}

This section presents concepts related to the three subjects - Knowledge Sharing, Social Capital theory and Social Media - with the purpose of preparing the reader for the following sections.

\subsection{What is Knowledge Sharing?}

Knowledge Sharing is one of the four KM processes. Although the idea of managing knowledge is ancient, with documented works attributed to Plato in 369 BC, it only became a discipline around the 1990's, triggered by the movement towards a knowledge-based economy (Serenko, 2013). Regarding the KM processes, while differences exist in the literature related to terminology and number, many scholars agree there are four main processes related to knowledge creation, storage, sharing and usage (Alavi and Leidner, 2001; Lee, 2001; Anand and Singh, 2011). Several scholars consider sharing the main process (Oliveira et al., 2015; Guinea, Webster and Staples, 2012; Kuo and Young, 2008), because it is seen as being essential for the generation of new ideas which may turn into competitive advantage (Grant, 1996).

When discussing Knowledge Sharing it is important to understand the definitions of two types of knowledge: tacit knowledge - which is held in the individual's mind and is related to one's expertise, or the know-how, and is considered more difficult to transmit and imitate; and explicit knowledge - which refers to knowledge that is already documented or codified, or the know-what, and is easier to communicate (Polanyi, 1966; Nonaka, 1994).

The concept of Knowledge Sharing comprises two parts: collecting - when someone consults others about what they know; and donating - when someone communicates to others what he or she knows (Hooff and Ridder, 2004). Therefore, Knowledge Sharing is the process that disseminates knowledge through the cycle of collection and donation - nurturing social media content and favouring from social capital relationships.

\subsection{Social Capital Theory}

This theory originated from Sociology in the 1980's and was introduced into Business and Management fields during the 1990's by Nahapiet and Goshal who drew on Coleman's studies (Filieri and Alguezaui, 2014). Essentially, this theory resides in networking relationships where social 
relations are the fuel that feeds the capital - which can be knowledge or any other capital - and may generate benefits based on feelings of gratitude, respect, and friendship or even rights derived from institutional membership (Nahapiet and Goshal, 1998; Bourdieu, 1986). Nahapiet and Goshal (1998) added the following three dimensions to the theory:

- Structural - refers to configuration of networks and social interactions between actors, an important facet of this dimension being the presence or absence of network ties between actors; network configuration, and appropriable organization in terms of network's usage;

- Relational - relates to the assets created from the relationship among individuals, which comprises the facets of trust and trustworthiness, norms and sanctions, obligations and expectations, and identity and identification;

- Cognitive - consists of a common system of meaning held among the parties and combines the facets of shared language and codes, and shared narratives.

When combining Social Capital theory with Social Media, one aspect that is often highlighted relates to the structural dimension through social interactions and the strength of the ties, whether strong or weak. For Granovetter (1973), weak ties consist of a low interaction frequency and a relational distance, which he considered enables access to new information; while strong ties, on the other hand, involve a high interaction frequency, a longer-standing relationship and relational proximity, enabling access to redundant information. These two types of ties may foster and transfer distinct types of knowledge. Although weak ties promote access to novel information and knowledge, they impede/obstruct the transfer of complex or non-codified knowledge (Filieri \& Alguezaui, 2014; Hansen, 1999). By contrast, strong ties facilitate the transfer of private, high-quality and tacit knowledge (Hansen, 1999, Uzzi and Lancaster, 2003; Reagans and McEvily, 2003).

\subsection{Social Media}

Social Media became popular at the beginning of this century and was mostly publicly consumed during the first years; studies suggest that it started being used within organizational environments between 2005 and 2010 (Kaplan and Haenlein, 2009; Kietzmann et al 2011). To highlight how widespread Social Media has become, taking Facebook, the leading Social Media tool as an example, it has nearly two billion registered and active monthly users worldwide (Socialbakers, 2017), representing nearly $40 \%$ of the world population (United Nations, 2017). Social media are being researched by scholars from different fields, as they affect and influence society in general, like interpersonal relations, civic engagement and news distribution and consumption (Kümpel, Karnowski and Keyling, 2015).

For the purpose of this paper, the definition of Social Media is "a group of Internet-based applications that build on the ideological and technological foundations of Web 2.0, and that allow the creation and exchange of user-generated content" (Kaplan and Haenlein, 2009, p.61). Social Media can be public - denoting the tools that are accessible by everyone who has internet access, or private - the tools that are used within organizations; although organizations may also use public tools. Despite accessibility conditions, Social Media can be classified as (Kaplan and Haenlein, 2009):

- Blogs;

- Social network sites. E.g. Facebook, Linkedin;

- Virtual social words. E.g. Second Life;

- Collaborative projects. E.g. Wikipedia;

- Content communities. E.g. YouTube;

- Virtual game worlds. E.g. World of Warcraft. 
After lagging behind the general public in terms of adoption, companies have been increasingly using Social Media to help them achieve their business objectives, like fostering internal collaboration, talent management and even operations (Kane, 2014). Some examples of private social media are tools like Yammer, Chatter and IBM Connection.

\subsection{Combining Knowledge Sharing, Social Capital and Social Media}

As knowledge sharing relies on communication among the parties - the collectors and donators (Hoof and Ridder, 2004), it also needs an infrastructure and resources to support that communication. Social Media provides the technology to establish and manage social networks in novel ways (Kane, 2014), connecting people and facilitating communication, while Social Capital brings people and their relationships together to create/make knowledge flow, which resides in people (Grant, 1996). Hence, one plays the infrastructure role and the other offers its resources, thus connecting Knowledge Sharing, Social Media and Social Capital. The next section describes the method used to collect and analyse the papers used in this review.

\section{METHOD}

This section details how the 22 papers related to the subjects Social Media, Social Capital and Knowledge Sharing were identified and analysed for this study; it is composed of two parts: papers selection criteria and the analysis of selected papers.

\subsection{Papers Selection Criteria}

Relevant papers were collected in early October 2017 from two databases: Scopus and Web of Science. First, in the Scopus database, the following keywords were sought as part of the title, abstract and/ or keywords of articles and conference papers: "Social Media" AND "Social Capital" AND ("Knowledge Sharing" OR "Knowledge Transfer"). The search produced 23 documents. After, a similar search was conducted in the Web of Science database, the same keywords were used in the 'topic' field limiting the type of documents to articles and proceedings papers; 20 documents were identified. Once the list of documents from both databases was available, a comparison was made to remove duplicate titles. Of the 43 documents, ten were repeated and removed from the list. A first triage was executed in the remaining 33 documents by reading their abstract, four documents were considered unrelated to the subject of the research and six others required more investigation, leaving 29 documents. The documents were then downloaded (except for three conference papers that were not found) and read by the author, 22 were considered pertinent for the research and four not, as the subject investigated was not developed further than the abstract.

\subsection{Analysis of Selected Papers}

The 22 documents were subjected to the following two processes:

1. The completion of a pre-defined form elaborated with the main aspects to be observed;

2. Three-step coding.

The first process consisted of reading each document and completing a spreadsheet with columns related to the aspects: reference, method, concept, objective and results. The second involved three-stage coding as in Matavire and Brown (2013): 
- Open coding - happens during the analytical process of reading the text and identifying concepts and categories within the data (text);

- Axial coding - happens during the process of relating sub-categories based on the previously defined categories;

- Selective coding - is the identification of core categories to which, in almost all cases, the other identified categories relate.

Creating the categories, which is part of coding processes, followed the categorization criteria according to Bardin (2011), observing the meaning of the subject. In the first stage, open coding consisted of reading the documents and completing the spreadsheet containing categories such as: motivation, barriers, benefits and strength of ties. Then, axial coding involved reading the extracts related to the previously defined categories and generating sub-categories, e.g.: collaboration, co-creation, strong ties, weak ties, trust, informal interactions, tacit knowledge. In the third and final stage, selective coding involved analysing all the categories and sub-categories to identify the following core categories: Network Ties, Tacit Knowledge and Participation.

\section{RESULTS AND DISCUSSION}

In the next four subsections, the results from the 22 papers are presented, analysed and discussed based on the four aspects observed during reading. The core categories produced by selective coding will be discussed in the last subsection.

\subsection{Analysis of Reference}

The papers analysed in this study were published between 2010 and 2017, indicating that this combination of subjects has only recently come under academic scrutiny, a few years after social media started being used for organizational purposes (Kaplan and Haenlein, 2009). Of the 22 papers, 13 were published in journals and nine in conferences; a complete list is available in appendix " $A$ ". The year 2015 saw the largest number of publications (seven). However, due to the small total number of papers, it is impossible to determine a trend. One reason for the low volume of papers might be the fact that some papers focus on specific types of social media (such as wiki, blogs, etc.), without mentioning the term "social media", and therefore would not have been identified in the initial search.

\subsection{Analysis of Research Methods, Types of Social Media and Areas}

Most of the studies were based on empirical research (17 out of 22). Of those, eleven involved quantitative studies, of which nine adopted a survey method, one used an experiment and the other failed to mention the method used. Data analysis was performed using Structural Equation Model (SEM) in eight studies, regression in two, and the agent-based simulation modelling method in the remaining one. Five papers adopted a qualitative approach, and one study used mixed methods; the case study method was applied in the five qualitative studies.

Regarding the types of social media considered, social networks predominated (see Table 1). Among the social network tools, Facebook was the prevailing tool, being present in eight studies, followed by Linkedin in two studies. Organizational and academic tools, such as Yammer and IBM Connections in the business context and Moodle, Pearltrees and ResearchGate in the academic context 
were also considered. Notably, public tools like Facebook were also found to be used for private or business purposes, as reported in the research by Bharati et al. (2015) in the context of organizations with intense use of knowledge; Lee \& Paris (2013) in their research of the events industry and Okazaki et al (2017), who compared Facebook and TripAdvisor for knowledge sharing among tourists.

Table 1 - Type of Social Media and number of publications.

\begin{tabular}{cc}
\hline Type of Social Media & Number of Papers \\
\hline Social network & 12 \\
Blog & 3 \\
Micro-blog & 2 \\
Wiki & 1 \\
Not specified & 9
\end{tabular}

Source: the authors.

Table 1 shows nine of the analysed papers did not specify any particular social media type, but rather adopted a broad coverage. On the other hand, some papers specified more than one type, such as social networks and micro-blog or even diverse types of social media tools, mixing social networks, blogs and micro-blogs, for instance.

Figure 1 details the areas and unities of analysis where the 17 empirical studies were researched. Although there is no concentration in any area, it can be seen that three studies were focused on individuals (Social Media users) and rest of them to diverse kinds of organizations.

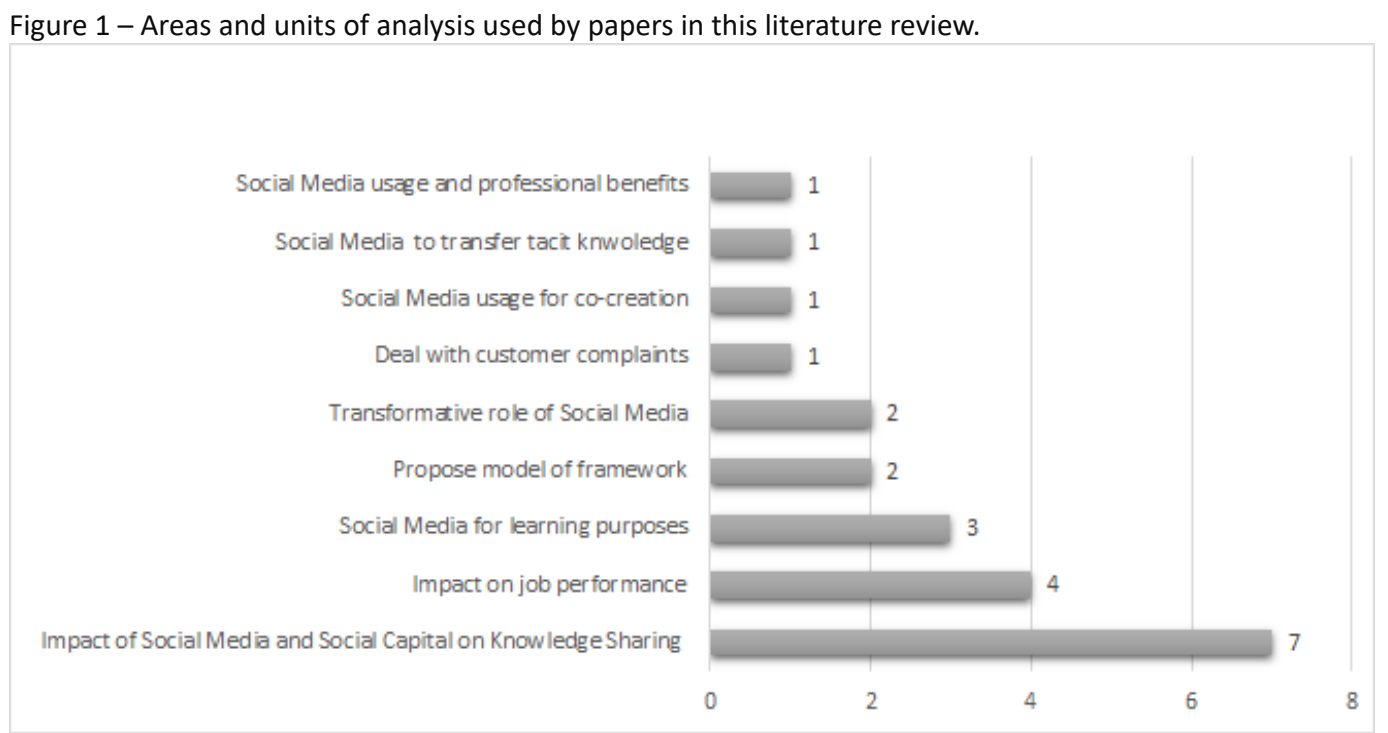

Source: the authors.

\subsection{Analysis of the Concepts}

This section describes how the three concepts are treated in the 22 analysed papers regarding factors like the direction of the relation, which theoretical dimensions were applied and the two main streams that emerged based on Social Media practice.

Social Capital is considered an antecedent of Knowledge Sharing in nine out of the 11 studies where it is possible to identify a relation, this is in alignment with other studies (Filieri \& Alguezaui, 2014; Chai \& Kim 2010). Social Capital's dimensions, represented by facets like social inter- 
actions, trust, identification and shared goals are thought to be of major importance for establishing relationships that will help disseminate knowledge. The two other papers presented an inverted flow, suggesting Knowledge Sharing influences Social Capital. In one of the studies, Baehr \& AlexBrown (2010) consider blogs as a knowledge sharing tool and analysed the impact on Social Capital, while in the other study Hajli (2013) considers Social Media developing the co-creation of value (that implies knowledge sharing) with consumers and, as a consequence, generating social capital. These two studies do not consider this inverted flow of Social Capital as a resource for facilitating knowledge sharing, but rather as an organizational asset that is impacted by Knowledge Sharing. The other nine papers show no such relationship.

Social Capital theory's Structural, Relational and Cognitive dimensions were used in 14 documents, in which facets of network interactions (structural dimension), trust (relational dimension) and shared goals (cognitive dimension) were intensively referenced. The concepts of bridging (related to ties among people of distinct characteristics) and bonding (related to ties among people of similar characteristics) were used with reference to the breadth and depth of network ties in seven documents.

Two main streams were identified when relating Social Media, knowledge sharing and Social Capital. One of the streams, identified in the majority of the papers, considers Social Media as a channel or tool that facilitates the flow or sharing of knowledge, allowing more informality during interactions and aiding the sharing of tacit knowledge. The other stream, identified in two papers, see Social Media as playing a transformative role within the organization. In the multiple case study from Makkonen \& Virtanen (2015), Social Media is thought to cause a social change in terms of how the organization communicates with partners and employees and suggests that, in all the cases studied it caused a cultural change, suggesting the need for attention regarding the opportunities and threats involved. The second research, involving a multiple case study among consulting companies in the United States, the author suggests Social Media leads to a digital transformation:

\begin{abstract}
"It is however important to note that the undergoing digital transformation is not only determined by social technologies and their unique features. The true benefits and transformative affordances of these technologies relative to informal KS is realized through a complex array of sociotechnical changes, shaped by both the use of technology and how workers interpret and appropriate them, and in a broader sense, factors such as culture and norms." (Jarrahi, 2017 p. 11).
\end{abstract}

Hence, in the first stream Social Media is thought to play an operational role and in the second stream, authors suggest Social Media plays a transformative role. According to Makkonen \& Virtanen (2015), in the second stream, Social Media can be perceived as either an opportunity and as a threat, depending on how organizations and individuals use it. Table 2 shows some examples related to the operational role and the two papers that suggest Social Media plays a transformative role.

Table 2 - The role of Social Media.

\begin{tabular}{|ccc|}
\hline Context & Role of Social Media & Reference \\
\hline $\begin{array}{c}\text { Doctors in rural areas of } \\
\text { Thailand }\end{array}$ & $\begin{array}{c}\text { Channel to share tacit knowledge between specialists } \\
\text { and young doctors }\end{array}$ & Somsakit et al. (2016) \\
\hline $\begin{array}{c}\text { Students in United } \\
\text { States }\end{array}$ & Tool (Facebook) to share knowledge among students & Alelyani et al. (2015) \\
\hline $\begin{array}{c}\text { Mix of industries (coun- } \\
\text { try not specified) }\end{array}$ & Transformative role - social and cultural changes & $\begin{array}{c}\text { Makkonen \& Virtanen } \\
\text { (2015) }\end{array}$ \\
\hline $\begin{array}{c}\text { Consulting companies in } \\
\text { United States }\end{array}$ & $\begin{array}{c}\text { Digital transformation - promotes sociotechnical } \\
\text { changes, shaped by both the use of technology and } \\
\text { how workers interpret and appropriate them. }\end{array}$ & Jarrahi, 2017 \\
\hline
\end{tabular}

Source: the authors. 


\subsection{Objectives and Results}

The papers were grouped according to the research objectives, which are listed in Figure 2. Seven papers aimed to investigate the impact of Social Media and Social Capital on Knowledge Sharing, while four papers sought to understand the impact of those three main elements on job performance.

Figure 2-Grouping of objectives x Number of studies.

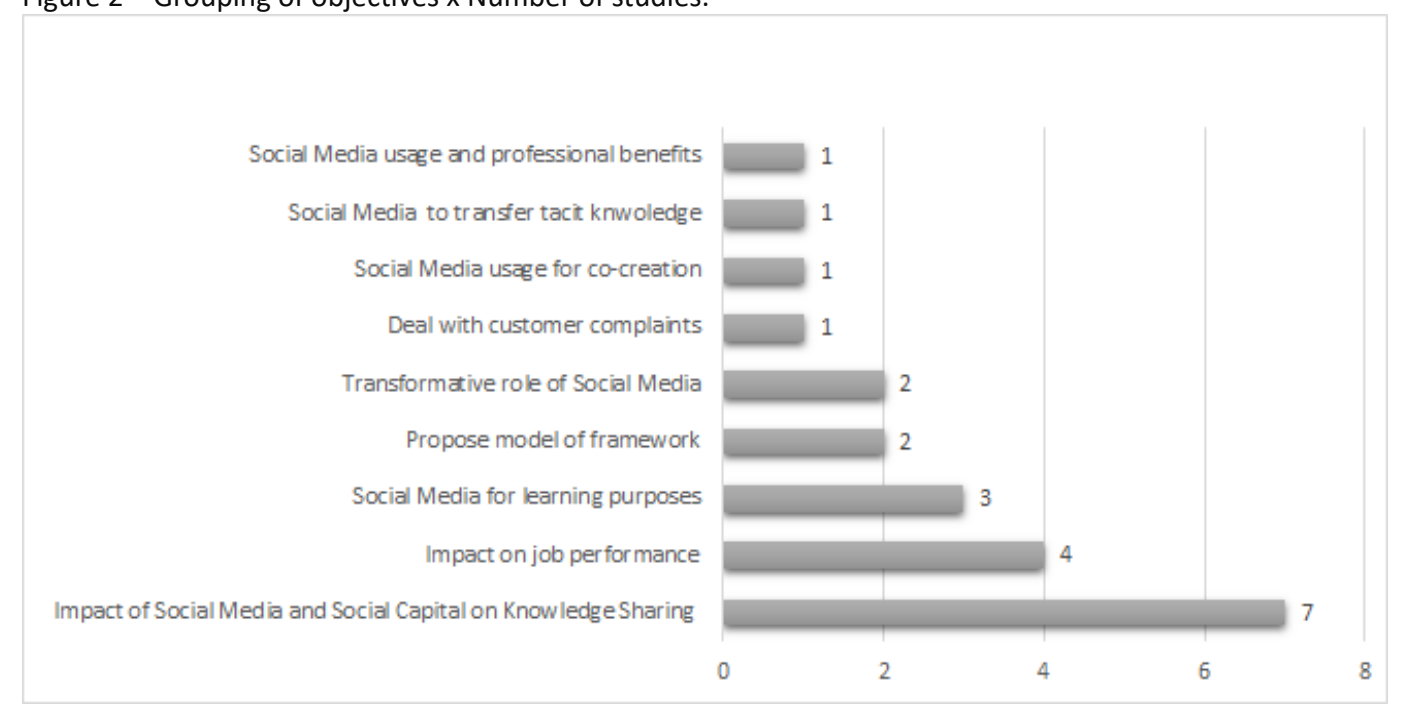

Source: the authors.

In terms of influence of Social Media and Social Capital, most of the studies indicate they improve knowledge-sharing activities, for instance, Bharati et al. (2015) suggest that "social media helps to provide the technical environment conducive to knowledge exchange and social capital enables the actual knowledge sharing between businesses". This finding is related to the context of Information Technology professionals in the United States. A study into how college and under-graduate students in United States use social media for learning (Alelyani et al., 2015), empirically concluded that Facebook was the most widely used tool and that a sense of belonging (identification) is a significant indicator of an individual's knowledge sharing in terms of quality.

Regarding research related to job performance, an empirical study among a mix of industries in China (Caoet al., 2016) explored the influence of Social Media on work performance and indicates the relative effectiveness of specific facets of Social Capital in shaping work performance. For example, 'shared vision' was found to positively influence work performance and be partially mediated by 'knowledge transfer', while, the facets 'network ties"' and 'trust' were found not to influence work performance. In another investigation into job performance, conducted among telecommunication companies in China, Lu et al. (2015) confirmed that using a work-related blog network, via the structural and cognitive dimensions of Social Capital positively affected job performance. There might be some concern among managers regarding employees being distracted by the use of Social Media tools at work. According to Kane (2014 p. 13), "the biggest impact on performance will likely come when employees use multiple content mechanisms that allow them to both explore and exploit the knowledge found on a platform", meaning the benefits should be greater than any hindrances to employee productivity.

In one way or another, most of the studies considered Social Media as a tool that, when combined with resources derived from Social Capital, facilitates the knowledge flow and produces 
benefits. By contrast, as mentioned in the previous section and Table 2, two papers introduced a divergent viewpoint, arguing that Social Media tools play an essentially transformative role, which may be used to support organizational strategy. Considering these latter two papers are recent and based on multiple case studies, implying a deep understanding of the context, their findings may indicate an evolution in the use of Social Media and thus deserve further investigation.

\subsection{Connecting Knowledge Sharing, Social Media and Social Capital}

Although the research combining the process of Knowledge Sharing with Social Media and Social Capital is scarce (only 22 pertinent papers were identified in this study), the three concepts may work on a complementary way, as it has been functioning in peers between Social Capital and Knowledge Sharing (Kim \& Lee, 2006; Chiu, Hsu \& Wang, 2006; Han \& Hovav, 2013) and between Social Media and Knowledge Sharing (Rode, 2016). This section presents a list of the benefits that emerged from the analysed papers (Table 3 ) and three main categories resulting from the selective coding - network ties, participation and tacit knowledge - suggesting they may connect the dots among the three concepts.

Table 3. Benefits identified in the analysed papers.

\begin{tabular}{ll}
\hline Benefit & Paper number as per appendix “A" \\
\hline Collaboration & $6,11,16,21,22,25,26,27$ \\
Cooperation & 2,25 \\
Informal interactions & $9,16,18,21,26$ \\
Innovation & $2,20,21,25$ \\
Improved Job performance & $6,16,19,21,25,27$ \\
Organization efficiency & $16,18,20$ \\
Privileged access to sources of knowledge & 18 \\
Professional advantages & 29 \\
\hline
\end{tabular}

Source: the authors.

The following subsections present and discuss the three main categories resulting from the three-stage coding process and suggest they may work as connecting point among the three subjects making them complement each other.

\subsubsection{Network Ties}

One aspect that stood out during the analysis of the papers and emerged as one of the core categories is network ties in terms of strength, depth and breadth. A tie's strength is defined in terms of "the amount of time, emotional intensity, or reciprocity between two actors in a network" (Jarrahi, 2017 p. 5). The concept of tie is part of the structural dimension of Social Capital theory and considered critical for knowledge sharing (Utz, 2016; Filieri and Alguezaui, 2014). Three forms of ties were identified:

- Strong tie: a connection that is characterized by a deep relation among individuals, usually family members or close friends and is instrumental for sharing more complex knowledge (Jarrahi, 2017, Utz, 2016);

- Weak tie: a connection among individuals with diverse backgrounds and without close relationship, for example, acquaintances or former colleagues (Jarrahi, 2017; Utz, 2016);

- Latent tie: meaning the potential connections that may occur through the social media's capabilities and social ties but have not happened yet (Manca and Raffaghelli, 2017; Utz, 2016). 
The relevance of network ties is mentioned in several of the analysed papers and considered essential for knowledge sharing in the context of social media (Jarrahi, 2017; Utz, 2016; Ellison, Gibbs \& Weber, 2015). Weak ties denote heterogeneous connections facilitating the emergence of novel information, ideas and the localization of expertise, which all generate knowledge (Ellison, Gibbs \& Weber, 2015; Burke et al., 2011; Ellison, Steinfield \& Lampe, 2007; Granovetter,1973). The concepts of bridging and bonding social capital are also related to tie strength. Bonding corresponds to the strong ties and bridging to the weak ties, the former implying deep relationships and the latter implying broad social relationships.

The importance of having a clear definition of what the organization or individual expects from social media is fundamental for defining a strategy to obtain the full benefits from Social Media usage. When complex knowledge is involved, despite the communication channel, strong ties are needed to facilitate the effective transfer of knowledge (Hansen, 1999; Reagans and McEvily, 2003; Utz, 2016). By contrast, weak ties may provide an individual with access to non-redundant information sources, as the knowledge seeker is not close, therefore the information that flows is more likely to be different from what the seeker already possesses (Levin, 2004, Burt, 1992), supporting the bridging social capital, hence facilitating the creation of heterogeneous knowledge. According to Fulk and Yuan (2013), having a broad network, because it involves diverse sources, can benefit the search for knowledge, considering people can rely on weak ties for novel subjects and on strong ties for support. Another means of enhancing the social network is to turn latent ties into weak ties (Manca and Raffaghelli, 2017).

\subsubsection{Tacit Knowledge}

The sharing of tacit knowledge has been a suited subject of consideration when combining Social Media, Social Capital and Knowledge Sharing concepts. Conventional KM systems, those that do not run on Web 2.0, focus on static knowledge, and are therefore less helpful for sharing tacit knowledge (Majchrzak et al., 2013; Fulk and Yuan, 2013, Panahi, Watson and Partridge, 2016). It has been suggested that Social Media tools are natural venues for sharing tacit knowledge because they facilitate informal, instant and more frequent interactions, which may generate trust (Jones, 2001; Bughin et al., 2009; Panahi, Watson \& Partridge, 2013), which is an important element in tacit knowledge sharing (Levin and Cross, 2004, Chiu, Hsu \& Wang, 2006).

In this study, over a third of the analysed papers emphasized Social Media as a facilitator of tacit knowledge sharing. Table 4 details some examples of how the authors approached this subject. The review of the literature reveals there is a growing interest in this connection. Panahi, Watson and Partridge (2016) stated that social media, compared with traditional systems, facilitated the sharing of tacit knowledge among physicians. Nevertheless, they also suggested it cannot yet replace face-to-face communication when the knowledge to be shared is highly tacit, due to the richer experience offered by person to person relations. Another empirical study (Kaya and Sagsan, 2015) on this same subject, concluded that the seniority of employees and the speed of adoption of innovation affects the capacity to both accumulate and transfer tacit knowledge. 
Table 4 - Approach related to Tacit Knowledge

\begin{tabular}{|c|c|c|}
\hline Approach & Context of Research & Reference \\
\hline Blog as a tool to capture tacit knowledge & $\begin{array}{l}\text { Case study with IT } \\
\text { industry in United } \\
\text { States }\end{array}$ & $\begin{array}{c}\text { Baehr \& } \\
\text { Alex-Brown } \\
(2010)\end{array}$ \\
\hline $\begin{array}{c}\text { Social Media facilitating informal knowledge activities like } \\
\text { sharing of tacit knowledge }\end{array}$ & $\begin{array}{l}\text { Multiple case study, } \\
\text { consulting compa- } \\
\text { nies in United States }\end{array}$ & Jarrahi, 2017 \\
\hline Propose sharing of tacit knowledge in Saudi Arabia firms & Literature Review & $\begin{array}{l}\text { Alelyani, } \\
2015\end{array}$ \\
\hline $\begin{array}{l}\text { Social Media relations based on trust increase tacit } \\
\text { Knowledge sharing and collaboration }\end{array}$ & $\begin{array}{l}\text { Young doctors in ru- } \\
\text { ral areas of Thailand }\end{array}$ & $\begin{array}{l}\text { Somsakit et } \\
\text { al (2016) }\end{array}$ \\
\hline $\begin{array}{l}\text { Use of electronic Community of Practice to share tacit } \\
\text { Knowledge }\end{array}$ & $\begin{array}{c}\text { Case study with IT } \\
\text { industry in United } \\
\text { States }\end{array}$ & $\begin{array}{l}\text { Kline \& Alex- } \\
\text { Brown, } 2013\end{array}$ \\
\hline
\end{tabular}

Source: the authors.

In summary, current research suggests Social Media facilitates the sharing of tacit knowledge especially when compared with traditional tools. However, context (such as the degree of tacitness and seniority) plays important role in terms of how effective the sharing will be.

\subsubsection{Participation}

For knowledge sharing to occur people are necessary, i.e. Social Capital, and, to conduct the fuel generated by people, i.e., knowledge, channels are needed, and, to connect people, many times geographically dispersed, social media has been proven to be very effective (Ellison, Gibbs \& Weber, 2015).

Human participation is essential to make the "Social Media-Social Capital" engine work and generate the knowledge to be shared. In the virtual context of social media, participation, that happens thru the social ties and can be triggered by different motivations, allows co-creation of content, which is one of the Social Media's capabilities. Hajli (2013) states that the social interaction of individuals through Social Media and online communities of practice has led to co-creation of value with customers, instead for consumers, producing organizational learning. On this same line, D'arisbo et al. (2016) also present the importance of interaction among people to stimulate co-creation, either face to face or via social media, because when people share ideas, new ideas show up.

These are examples of interorganizational knowledge sharing, when co-creation occurs with consumers, which may even turn into innovative solutions. Another example is provided in the multiple case study conducted by Makkonen and Virtanen (2015), which found that one of the benefits of implementing social media was the change in the way the organization communicates, facilitating a social approach and allowing more dialogue and co-creation with and among the employees, leading to a cultural change.

Social Media also has the synchronous capability, which facilitates informal conversations, shortens distances and can generate stronger ties. Trust, which is part of the relational dimension of Social Capital has been shown to influence knowledge sharing, especially for tacit knowledge, by various studies (Levin and Cross, 2004; Chieu at al 2006; Whiterspoon, 2013). The study by, Somsakit et al (2016), presented a situation where the use of social media enabled young doctors in rural areas of Thailand to frequently interact with specialists in metropolitan areas, which turned into a trustbased/trustful and collaborative relationship that enabled these young doctors to better support local ill people looking for medical help. 


\subsection{Research Agenda}

The joint analysis of the three subjects, Social Media, Social Capital and Knowledge Sharing enabled the identification of the main characteristics and contributions related to each subject as shown in Figure 3. In addition, there are also topics that deserve further investigation either because previous studies have not been conclusive or for not having been extended yet, as can also be seen in Figure 3 .

Figure 3: Topics covered by analysed papers $\mathrm{x}$ Topics needing further research.
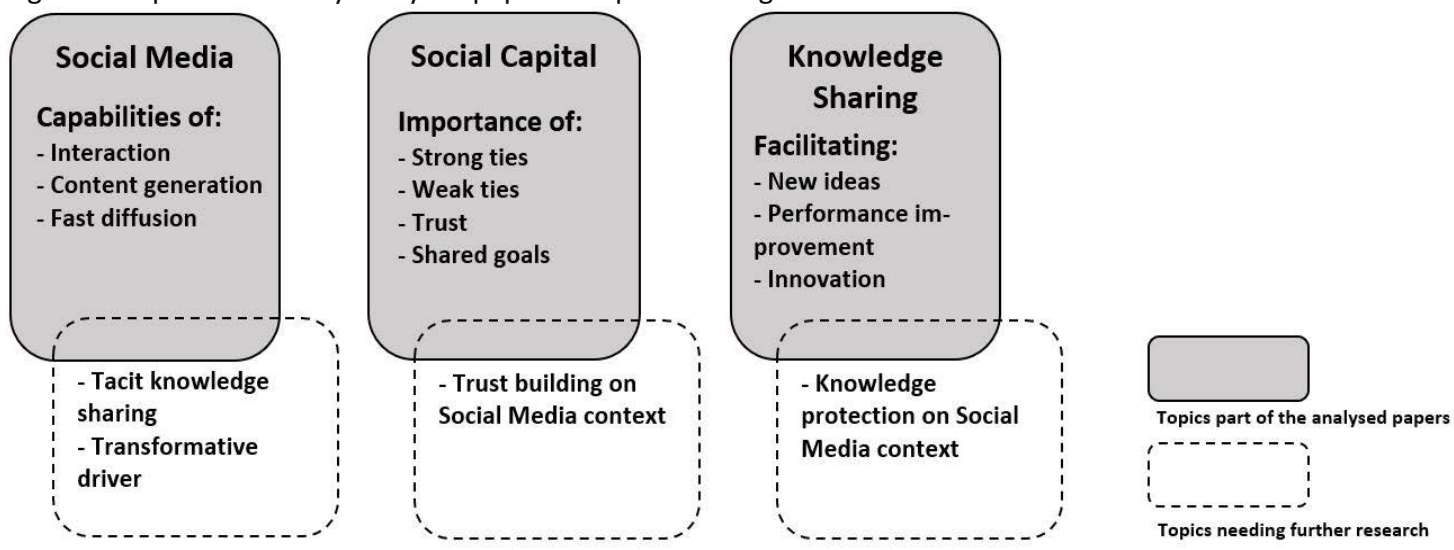

Source: the authors.

Although some empirical studies (Somsakit et al., 2016; Kline and Alex-Brown, 2013) have indicated positive outcome about sharing tacit knowledge via Social Media tools, this topic requires further research focusing on different contexts. As mentioned in the previous section positing the status of Tacit Knowledge as a core category, this is still a controversial subject and additional investigation might at least indicate any features that are still lacking to get Social Media comparable to face-to-face interactions. Another topic worthy of further investigation is the Social Media's role as a transformative driver for organizations. This idea differs greatly from that of other papers and probably deserves more qualitative research to highlight and validate propositions.

Regarding Social Capital, the analysed papers offered rich insights into the relevance of network ties, especially in relation to their relative strength, which represents the theory's structural dimension. The cognitive dimension was also covered especially, in relation to the importance of having shared vision and common language, facilitating the flow of knowledge in channels like online communities. However, the present study suggests the need for deeper analysis into how to build trust through Social Media tools, as this is a key element for having strengthening ties, and consequently influences the sharing of tacit knowledge.

Finally, in terms of Knowledge Sharing, the papers presented a variety of situations and contexts where this process had a positive impact/influence on innovation and improved job performance, for instance. When combined with Social Media and Social Capital, Knowledge Sharing nurtures learning, co-creation of content and value. In this context, one item requires further research - knowledge protection, that is, preventing the sharing any knowledge considered confidential for a specific operation or that may represent a competitive advantage. Social Media and Social Capital together can reach a wide audience, which in some situations can be a risk. Therefore, it is essential to have a strategy for using them in order to ensure there is no damage to the personal or organizational image or even loss of competitive advantage. 


\section{CONCLUSION}

This study analysed 22 pertinent papers that combine the subjects of Social Media, Social Capital theory and Knowledge Sharing, and outlines how they relate to each other, the benefits of combining them and suggests opportunities of further research. The empirical results from the papers, along with theoretical support, clearly highlight the importance of Social Media tools as channels facilitating knowledge flow. These channels are enhanced by the resources leveraged from Social Capital theory, like the network ties and their strength, trust and shared goals. Once knowledge is shared, it works as a fuel for people to have new ideas and then improve processes and performance, innovate and generate competitive advantages, which are some of the known benefits of effective knowledge management (Davenport \& Prusak, 1998; Lee, 2001; Oliveira et al., 2015).

In terms of academic contributions, this study adds to the literature of the three areas (Social Media, Social Capital and Knowledge Management) by:

- Detailing the direction of relations, pointing out how Social Capital theory and its dimensions are used and shedding light on the benefits of combining these subjects;

- Highlighting the potential for Social Media tools to become more than channels and assume a transformative role;

- Suggesting an agenda related to the importance of protecting the knowledge that cannot be shared and developing more empirical research into the sharing of tacit knowledge via Social Media.

For practitioners, this study offers a consolidated view highlighting how powerful Social Media has become in public and private spheres and suggests the need to build strategies (organizational and individual) to ensure the full benefits are obtained from it, considering the particular individual or organizational context. Some of the main points presented in this study that can be applied to diverse types of organizations are:

- Having a strategy for Social Media use;

- Importance of fostering strong and weak ties;

- Motivating participation;

- Spurring tacit knowledge flow.

The limitation of this study is related to the limited number of papers that resulted from the search. Adding specific names of Social Media tools to the searched keywords will likely increase the number of papers retrieved and extend the scope of the study.

\section{ACKNOWLEDGEMENTS}

The authors are grateful for the support provided by CNPq (Conselho Nacional de Desenvolvimento Científico e Tecnológico - Brazil) and FCT (Fundação para a Ciência e Tecnologia, Portugal), national funding through research grant UIDB/04521/2020. 


\section{REFERENCES}

ALAVI, Maryam; LEIDNER, Dorothy E. Knowledge management and knowledge management systems: Conceptual foundations and research issues. MIS quarterly, p. 107-136, 2001.

ALELYANI, Turki et al. Not just silly cat videos: Exploring student knowledge sharing via social media. 2015.

ANAND, Apurva; SINGH, M. D. Understanding knowledge management. International Journal of Engineering Science and Technology, v. 3, n. 2, p. 926-939, 2011.

BAEHR, Craig; ALEX-BROWN, Konstanze. Assessing the value of corporate blogs: A social capital perspective. IEEE Transactions on Professional Communication, v. 53, n. 4, p. 358-369, 2010.

BECK, Roman; PAHLKE, Immanuel; SEEBACH, Christoph. Knowledge exchange and symbolic action in social media-enabled electronic networks of practice: A multilevel perspective on knowledge seekers and contributors. MIS quarterly, v. 38, n. 4, p. 1245-1270, 2014.

BHARATI, Pratyush; ZHANG, Wei; CHAUDHURY, Abhijit. Better knowledge with social media? Exploring the roles of social capital and organizational knowledge management. Journal of Knowledge Management, v. 19, n. 3, p. 456-475, 2015.

BOURDIEU, P. The forms of capital, in RICHARDSON, J.G. (Ed.), Handbook of Theory and Research for the Sociology of Education, Greenwood Press, New York, NY, pp. 241-258, 1985

BUGHIN, Jacques; CHUI, Michael. The rise of the networked enterprise: Web 2.0 finds its payday. McKinsey quarterly, v. 4, p. 3-8, 2010.

BURKE, Moira; KRAUT, Robert; MARLOW, Cameron. Social capital on Facebook: Differentiating uses and users. In: Proceedings of the SIGCHI conference on human factors in computing systems. ACM, 2011. p. 571-580.

BURT, R. Structural holes. Cambridge, MA: Harvard University Press, 1992.

$\mathrm{CAO}$, Xiongfei et al. Exploring the influence of social media on employee work performance. Internet Research, v. 26, n. 2, p. 529-545, 2016.

CHAl, Sangmi; KIM, Minkyun. What makes bloggers share knowledge? An investigation on the role of trust. International journal of information management, v. 30, n. 5, p. 408-415, 2010.

CHIU, Chao-Min; HSU, Meng-Hsiang; WANG, Eric TG. Understanding knowledge sharing in virtual communities: An integration of social capital and social cognitive theories. Decision support systems, v. 42, n. 3, p. 1872-1888, 2006.

D’ARISBO, Anelise et al. Criação de conhecimento sob a ótica da aprendizagem organizacional em uma empresa criativa. Revista de Administração da Universidade Federal de Santa Maria, v. 9, n. 1, p. 83-101, 2016.

DAVENPORT, T. H.; PRUSAK, L. Working knowledge: How organizations manage what they know. Harvard Business Press, 1998.

ELLISON, Nicole B.; GIBBS, Jennifer L.; WEBER, Matthew S. The use of enterprise social network 
sites for knowledge sharing in distributed organizations: The role of organizational affordances. American Behavioral Scientist, v. 59, n. 1, p. 103-123, 2015.

ELLISON, Nicole B.; STEINFIELD, Charles; LAMPE, Cliff. The benefits of Facebook "friends:" Social capital and college students' use of online social network sites. Journal of computer-mediated communication, v. 12, n. 4, p. 1143-1168, 2007.

FILIERI, Raffaele; ALGUEZAUI, Salma. Structural social capital and innovation. Is knowledge transfer the missing link?. Journal of knowledge management, v. 18, n. 4, p. 728-757, 2014.

FULK, Janet; YUAN, Y. Connie. Location, motivation, and social capitalization via enterprise social networking. Journal of Computer-Mediated Communication, v. 19, n. 1, p. 20-37, 2013.

GRANOVETTER, M. S. The strength of weak ties. American journal of sociology, 78(6), 1360-1380, 1973.

GRANT, Robert M. Toward a knowledge-based theory of the firm. Strategic management journal, v. 17, n. S2, p. 109-122, 1996.

GUINEA, A. O.; WEBSTER, J., STAPLES, D. S. A meta-analysis of the consequences on team functioning, Information \& Management, v. 49, n. 6, p. 301-308. 2012.

HAJLI, Mahmood; HAJLI, Mohammad. Organisational development in sport: co-creation of value through social capital. Industrial and Commercial Training, v. 45, n. 5, p. 283-288, 2013.

HAN, JinYoung; HOVAV, Anat. To bridge or to bond? Diverse social connections in an IS project team. International Journal of Project Management, v. 31, n. 3, p. 378-390, 2013.

HANSEN, Morten T. The search-transfer problem: The role of weak ties in sharing knowledge across organization subunits. Administrative science quarterly, v. 44, n. 1, p. 82-111, 1999.

HOLSTE, J. Scott; FIELDS, Dail. Trust and tacit knowledge sharing and use. Journal of knowledge management, v. 14, n. 1, p. 128-140, 2010.

JARRAHI, Mohammad Hossein. Social Media, Social Capital, and Knowledge Sharing in Enterprise. IT Professional, v. 20, n. 4, p. 37-45, 2017.

JONES, Patricia M. Collaborative knowledge management, social networks, and organizational learning. Systems, Social and Internationalization Design Aspects of Human-Computer Interaction, v. 2, p. 306-309, 2001.

KANE, Gerald C. Enterprise social media: Current capabilities and future possibilities. MIS Quarterly Executive, v. 14, n. 1, 2015.

KANKANHALLI, Atreyi; TAN, Bernard CY; WEI, Kwok-Kee. Contributing knowledge to electronic knowledge repositories: An empirical investigation. MIS quarterly, v. 29, n. 1, 2005.

KAPLAN, Andreas M.; HAENLEIN, Michael. Users of the world, unite! The challenges and opportunities of Social Media. Business horizons, v. 53, n. 1, p. 59-68, 2010.

KAYA, Tugberk; SAGSAN, Mustafa. The impact of tacit knowledge capacity on social media: an empirical research on physicians in north Cyprus. In: 12th International Conference on Intellectual Capital, Knowledge Management and Organisational Learning. 2015. p. 133-141. 
KIETZMANN, Jan $\mathrm{H}$. et al. Social media? Get serious! Understanding the functional building blocks of social media. Business horizons, v. 54, n. 3, p. 241-251, 2011.

KIM, Soonhee; LEE, Hyangsoo. The impact of organizational context and information technology on employee knowledge-sharing capabilities. Public administration review, v. 66, n. 3, p. 370385, 2006.

KLINE, Joel; ALEX-BROWN, Konstanze. The social body of knowledge: nurturing organizational social capital via social media based communities of practice. Technical Communication, v. 60, n. 4, p. 279-292, 2013.

KUO, Feng-Yang; YOUNG, Mei-Lien. Predicting knowledge sharing practices through intention: A test of competing models. Computers in Human Behavior, v. 24, n. 6, p. 2697-2722, 2008.

KWAHK, Kee-Young; PARK, Do-Hyung. The effects of network sharing on knowledge-sharing activities and job performance in enterprise social media environments. Computers in Human Behavior, v. 55, p. 826-839, 2016.

LEE, Jae-Nam. The impact of knowledge sharing, organizational capability and partnership quality on IS outsourcing success. Information \& management, v. 38, n. 5, p. 323-335, 2001.

LEE, Woojin; PARIS, Cody Morris. Knowledge sharing and social technology acceptance model: Promoting local events and festivals through Facebook. Tourism Analysis, v. 18, n. 4, p. 457469, 2013.

LEVIN, Daniel Z.; CROSS, Rob. The strength of weak ties you can trust: The mediating role of trust in effective knowledge transfer. Management science, v. 50, n. 11, p. 1477-1490, 2004.

LU, Benjiang et al. Corporate blogging and job performance: Effects of work-related and nonworkrelated participation. Journal of Management Information Systems, v. 32, n. 4, p. 285-314, 2015.

MAKKONEN, Hannu; VIRTANEN, Kustaa. Social capital approach on Enterprise 2.0: A multiple case study. Technology Analysis \& Strategic Management, v. 27, n. 10, p. 1212-1225, 2015.

MANCA, Stefania; RAFFAGHELLI, Juliana Elisa. Towards a multilevel framework for analysing academic social network sites: a networked socio-technical perspective. In: Proceedings of the 4th European Conference on Social Media-ECSM. 2017. p. 193-201.

MATAVIRE, Rangarirai; BROWN, Irwin. Profiling grounded theory approaches in information systems research. European Journal of Information Systems, v. 22, n. 1, p. 119-129, 2013.

NAHAPIET, Janine; GHOSHAL, Sumantra. Social capital, intellectual capital, and the organizational advantage. Academy of management review, v. 23, n. 2, p. 242-266, 1998.

NONAKA, Ikujiro. A dynamic theory of organizational knowledge creation. Organization science, $v$. 5, n. 1, p. 14-37, 1994.

OKAZAKI, Shintaro; ANDREU, Luisa; CAMPO, Sara. Knowledge sharing among tourists via social media: A comparison between Facebook and TripAdvisor. International Journal of Tourism Research, v. 19, n. 1, p. 107-119, 2017. 
OLIVEIRA, Mírian et al. Using alternative scales to measure knowledge sharing behavior: Are there any differences?. Computers in Human Behavior, v. 44, p. 132-140, 2015.

PANAHI, Sirous; WATSON, Jason; PARTRIDGE, Helen. Conceptualising social media support for tacit knowledge sharing: physicians' perspectives and experiences. Journal of Knowledge Management, v. 20, n. 2, p. 344-363, 2016.

PANAHI, Sirous; WATSON, Jason; PARTRIDGE, Helen. Social media and tacit knowledge sharing: Developing a conceptual model. World academy of science, engineering and technology, n. 64, p. 1095-1102, 2012.

PANAHI, Sirous; WATSON, Jason; PARTRIDGE, Helen. Towards tacit knowledge sharing over social web tools. Journal of Knowledge Management, v. 17, n. 3, p. 379-397, 2013.

POLANYI, Michael. The Tacit Dimension Doubleday and Co. Garden City, NY, 1966.

REAGANS, Ray; MCEVILY, Bill. Network structure and knowledge transfer: The effects of cohesion and range. Administrative science quarterly, v. 48, n. 2, p. 240-267, 2003.

RODE, Henning. To share or not to share: the effects of extrinsic and intrinsic motivations on knowledge-sharing in enterprise social media platforms. Journal of Information Technology, v. 31, n. 2, p. 152-165, 2016.

SERENKO, Alexander. Meta-analysis of scientometric research of knowledge management: discovering the identity of the discipline. Journal of Knowledge Management, v. 17, n. 5, p. 773-812, 2013.

SOCIALBRAKERS. Facebook statistics by country. Available at: www.socialbakers.com/facebookstatistics. Accessed on Nov, 03, 2017.

SOMSAKIT, Nattapong; FUNILKUL, Suree; SUPASITTHIMETHEE, Umaporn. Importance Factors Influencing the Thai Doctors in Rural Area to Use Public Social Media for Work-Related Use: A Case Study of LINE Application.

UNITED NATIONS. UN News Centre. Available at: www.un.org/apps/news/story.asp?NewsID=57028\#. Wfya1mhSxPY. Accessed on Nov 03, 2017.

UTZ, Sonja. Is LinkedIn making you more successful? The informational benefits derived from public social media. New Media \& Society, v. 18, n. 11, p. 2685-2702, 2016.

UZZI, Brian; LANCASTER, Ryon. Relational embeddedness and learning: The case of bank loan managers and their clients. Management science, v. 49, n. 4, p. 383-399, 2003.

\section{APPENDIX “A”}

(2) Bharati, P., Zhang, W., \& Chaudhury, A. (2015). Better knowledge with social media? Exploring the roles of social capital and organizational knowledge management. Journal of Knowledge Management, 19(3), 456-475.

(6) Cao, X., Guo, X., Vogel, D., \& Zhang, X. (2016). Exploring the influence of social media on employee work performance. Internet Research, 26(2), 529-545.

(9) Fulk, J., \& Yuan, Y. C. (2013). Location, motivation, and social capitalization via enterprise social networking. Journal of Computer-Mediated Communication, 19(1), 20-37. 
(11) Wu, Y. L., Li, E. Y., \& Chang, W. L. (2016). Nurturing user creative performance in social media networks: An integration of habit of use with social capital and information exchange theories. Internet Research, 26(4), 869-900.

(16) Makkonen, H., \& Virtanen, K. (2015). Social capital approach on Enterprise 2.0: A multiple case study. Technology Analysis \& Strategic Management, 27(10), 1212-1225.

(18) Jarrahi, M. H. (2017). Social Media, Social Capital, and Knowledge Sharing in an Enterprise. IT Professional, IEEE.

(20) Kline, J., \& Alex-Brown, K. (2013). The social body of knowledge: nurturing organizational social capital via social media based communities of practice. Technical Communication, 60(4), 279-292.

(21) Ellison, N. B., Gibbs, J. L., \& Weber, M. S. (2015). The use of enterprise social network sites for knowledge sharing in distributed organizations: The role of organizational affordances. American Behavioral Scientist, 59(1), 103-123.

(25) Lu, B., Guo, X., Luo, N., \& Chen, G. (2015). Corporate Blogging and Job Performance: Effects of Work-related and Nonwork-related Participation. Journal of Management Information Systems, 32(4), 285-314.

(26) Alsaleh, G. (2015) EXPLORING THE USE OF SOCIAL MEDIA FOR TRANSFERRING KNOWLEDGE IN THE BUSINESS ENVIRONMENT. In: ADVED15 International Conference on Advances in Education and Social Sciences.

(27) Somsakit, N., Funilkul, S., \& Supasitthimethee, U. Importance Factors Influencing the Thai Doctors in Rural Area to Use Public Social Media for Work-Related Use: A Case Study of LINE Application.

(29) Utz, S. (2016). Is LinkedIn making you more successful? The informational benefits derived from public social media. New Media \& Society, 18(11), 2685-2702. 


\section{AUTHORS}

\section{Rosangela Fritscher Santos}

Master's degree at Pontifical Catholic University of Rio Grande do Sul (PUCRS), School of Business, Brazil in 2019; has a bachelor degree in Computer Science from PUCRS, specialization in General Management (UFRGS) and in People Management (UNISINOS).

E-mail: ro.fritscher@gmail.com

ORCID: https://orcid.org/0000-0003-2192-212X

\section{Mirian Oliveira}

Professor and researcher at Business School (PUCRS, Brazil) and invited professor at ISEG (University of Lisbon, Portugal). Doctoral degree in Business Administration from the UFRGS in 1999.

E-mail: miriano@pucrs.br

ORCID: http://orcid.org/0000-0002-5498-0329

\section{Marcirio Silveira Chaves}

Associate Professor in the Business School at Pontifical Catholic University of Rio Grande do Sul (PUCRS). Ph.D. in Informatics at University of Lisbon, Portugal.

E-mail: marcirio.chaves@pucrs.br

ORCID: http://orcid.org/0000-0002-3554-0328

\section{Contribution of authors}

\begin{tabular}{|c|c|c|c|}
\hline Contribution & [Author 1] & [Author 2] & [Author 3] \\
\hline 1. Definition of research problem & $\overline{\mathrm{V}}$ & & $\sqrt{\mathrm{V}}$ \\
\hline $\begin{array}{l}\text { 2. Development of hypotheses or research questions } \\
\text { (empirical studies) }\end{array}$ & Not applicable & Not applicable & Not applicable \\
\hline $\begin{array}{l}\text { 3. Development of theoretical propositions } \\
\text { (theoretical work) }\end{array}$ & $\sqrt{ }$ & $\sqrt{ }$ & \\
\hline 4. Theoretical foundation / Literature review & $\sqrt{ }$ & & \\
\hline 5. Definition of methodological procedures & $\sqrt{ }$ & $\sqrt{ }$ & $\sqrt{ }$ \\
\hline 6. Data collection & $\mathrm{V}$ & & \\
\hline 7. Statistical analysis & Not applicable & Not applicable & Not applicable \\
\hline 8. Analysis and interpretation of data & $\mathrm{V}$ & $\sqrt{ }$ & \\
\hline 9. Critical revision of the manuscript & & $\bar{V}$ & $\bar{V}$ \\
\hline 10. Manuscript writing & $\mathrm{V}$ & $\mathrm{V}$ & \\
\hline 11. Other (please specify) & & & \\
\hline
\end{tabular}

\section{Conflict of Interest}

The authors have stated that there is no conflict of interest.

\section{Copyrights}

ReA/UFSM owns the copyright to this content.

\section{Plagiarism Check}

The ReA/UFSM maintains the practice of submitting all documents approved for publication to the plagiarism check, using specific tools, e.g.: CopySpider. 